УАK 342.4

ББК 67.400 .2

DOI 10.22394/1682-2358-2018-5-6-15

P.A. Astafichev, Doctor of Sciences (Law), Professor of the Constitutional and International Law Department, St. Petersburg University of the Ministry of Internal Affairs of Russia

\section{REPRESENTATIVE DEMOCRACY \\ IN RUSSIA: \\ 25 YEARS UNDER THE CONDITIONS OF THE RUSSIAN FEDERATION CONSTITUTION OF 1993}

The problems associated with the experience of functioning of representative democracy in Russia after the adoption of the Constitution of the Russian Federation of 1993 are studied. The author draws attention to three problems: the balance of powers, the relationship of professional representation and combining the deputy mandate with the basic work, and the role of political parties in popular representation.

Key words and word-combinations: popular representation, constitutional principles, separation of powers, political parties, anniversary of the Constitution of the Russian Federation.
П.А. Астафичељ, доктор юридиеских наук, профессор кафедрьг конституционного и международного права Санкт-Петербургского yнubepcumema MBА Poсcuu (email:pavel-astafichev@ rambler.ru)

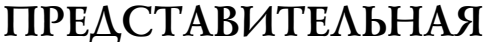
АЕМОКРАТИЯ В РОССИИ: \section{$25 \Lambda$ АТ В УС ОВИЯХ АЕЙСТВИЯ КОНСТИТУЦИИ РФ 1993 года}

Аннотация. Исследуются проблемы, связанные с функционированием представительной демократии в России после принятия Конституции РФ в 1993 г. Автор обращает внимание на три проблемы: баланс полномочий; соотношение профессионального представительства и совмещения депутатского мандата с основной работой; роль политических партий в народном представительстве.

Ключевые слова и словосочетания: народное представительство, конституционные принципы, разделение властей, политические партии, юбилей Конституции РФ.

K дарственное и правовое. Вне государства и права рассуждения о конституционализме бессмысленны. Нельзя говорить о конституционализме, например, в семейных или корпоративных отношениях, хотя в них реализуются многие конституционные принципы и данные отношения Аолжны отвечать требованию конституционности. Конститущионализм неразрывно связан с 
государством и правом. Конституционализм - это одна из форм государства и права. Конституџионализм не совместим с анархизмом. Феномен конституџионализма сопряжен с такими категориями, как «государство», «государственный суверенитет» и «государственная власть» $[1 ; 2$, с. 31; 3].

Мы живем не в естественном состоянии. Наша жизнь протекает в условиях государственности. Но это не означает, что государство - безусловное благо. Государственную власть можно обожествцять или, напротив, отрицать. Факт эмпирической государственной жизни не доказывает, что она необхоАима. Если государство - это «змо», то в долгосрочной перспективе следовало бы отказаться от государственной формы жизнедеятельности. Если же государство - «благо», то следует эту форму необходимо всецело поддерживать. Конџепция конституџионализма занимает своего рода промежуточную позицию: не отриџая полезность государства, она стремится его усовершенствовать посредством ряда институциональных юридических ограничений. Но конституционализм (это очень важно) не анархичен [4] .

Конституционализму как форме государственности противостоит позиция анархизма. Анархисты отрицают государственную власть, считая государство зАом. Не стоит полностью отметать эту позиџию как государственно вреАную, потому что анархизм имеет свою систему научной аргументации, с которой следует, как минимум, ознакомиться. Критикуя государство как институт, анархисты обосновывают мнение о вредности государственных учреждений [5]. Их аргументы могут использовать и конститущионалисты, цемь которых заключается в усовершенствовании государственной власти без ее всеобщего отрицания $[6 ; 7$, с. 16$]$.

Основной аргумент анархистов состоит в генеалогии государств и сущности пубцичной власти. Никто точно не знает, каким именно образом государства возникли, из каких форм они произошли. Существует масса разнообразных теорий на этот счет. Бесспорно одно: первые государства были весьма похожи на некоторые, не вполне мегитимные организаџии, целью которых явмялось совсем не обеспечение «благосостояния своих подАанных» или гарантирование «счастья мюдей на этой земле». Различие между «протогосударствами» и, к примеру, незаконными вооруженными формированиями еАва ощутимо. Государство - это всегда власть и принуждение. Государство по своему происхождению - Аалеко не гуманистический институт. Государственная власть пробивала себе дорогу симой и оружием, что нередко сопровождалось смертью тех, кто этой воле сопротивлялся. Ао сих пор в основе конџепџии государства цежит суверенитет, то есть целостная, независимая и верховная власть. Государство опирается на аппарат принуждения, вкАючающий вооруженные силы, полицию и спецслужбы.

Государство - это соџиальный институт, который наряАу с Аругими субътектами властных отношений заботится о самосохранении. В юридической науке этот феномен чаще всего характеризуют термином «государственная безопасность». Государству угрожкают извне Аругие страны; всегда существуют антигосударственные симы внутри него. Чтобы не быть уничтоженным, государство Аолжно этим угрозам эффективно противостоять [8, с. 19; 9]. Вооружен- 
ная агрессия извне пресекается ответным применением вооруженной силы. Аля преАотвращения беспорядков используются полиџейские или армейские подразделения. Государство офиџиально осуществляет разведывательную и контрразведывательную деятельность. В целях противодействия преступности имеется пенитенциарная система. В странах, признающих смертную казнь, Аопускается целенаправленное $и$ шение жизни особо опасных преступников по решению судебных органов уголовной юстиции. Но и в тех странах, которые отказацись от института смертной казни, государственные органы при определенных обстоятельствах имеют право на применение вооруженной

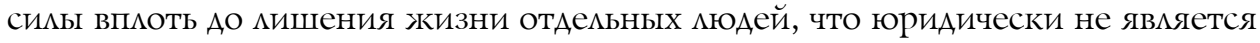
правонарушением. Это допускается в мирное время (абсолютно необходимое применение силы для защиты от противоправного насилия; законного задержкания ици предотвращения побега; подавмения бунта ици мятежка), а также в условиях войны.

Несмотря на убедительность этих доводов, важно видеть и Аругое: вне государственной формы организации жкизнедеятельности общества последнее рискует быть повергнутым в хаотическую пучину притязаний на власть со стороны его неофициальной части, в частности бандитов, насильников, мошенников, авантюристов и т.А. Власть представцяет собой ресурс, пользующийся удивительным спросом в обществе. Как только суверенный субъект от него отказывается, неизбежкно появцяются новые претенденты, причем Аля этих обновляемых отношений характерна тенденџия устойчивого убывания ответственности за использование ресурса власти человека над человеком.

Будучи офиџиальными, публичными, исторически апробированными, государства продолжают Аоказывать свою полезность наряду с некоторыми изАержками в виде политических ошибок, перегибов, искривлений, неверных приоритетов и т.п. Но главное, они противостоят стихийным противоправным силам, наличием которых в обществе нельзя пренебрегать. Если бы гражданские общества состояли искмючительно из «нравственно чистых и совершенных» инАивидов, госуАарственную власть, пожкацуй, Аействительно следовало бы отрицать как неоправданное и чрезмерное вмешательство в гражданские свободы. Но здоровый прагматизм в совокупности с имеющимися эмпирическими данными подсказывают, что это, увы, совершенно не так. Вследствие несовершенства человеческой природы, а также недостатков в воспитании и социальной культуре современным обществам однозначно нужны государства. В современном, цивилизованном мире они должны соответствовать общепризнанным критериям демократичности и конститущионности [10; 11] .

В декабре 2018 г. Аействующей Конституции РФ исполняется 25 мет. Конституция не ускорила ход истории, продолжительность ее Аействия не явцяется доказательством дальности пройденного ею пути. ОАнако условия, в которых принималась Конституция РФ, были иными по сравнению с современным этапом развития отечественной государственности. В свою очередь, в 1993 г. было невозможно преАвидеть эмпирические обстоятельства, при которых будет функщионировать российский конституџионализм 2018 г. В 1993 г. не только не было крупных проявлений «враждебности» к западной политической куль- 
туре, она преимущественно культивировалась, законодатель в значительной степени стремился к преодолению противоборства «западничества» и «славянофильства». Царящие умонастроения были направлены в пользу учреждения высших и универсальных принципов конституционной юриспруденции. Оптимистические имлюзии подАерживацись растущими возможностями конституционного правосудия обеспечивать Аействительно верховенствующее положкение Конституции в Аемократическом обществе. Аоказательств тому немало: мораторий на смертную казнь, судебный порядок принятия решения о содержании под стражей на срок свыше двух суток, исключительно законодательная форма введения налогов и сборов и т.А. Все это появилось и утвердицось в правовой системе России благодаря Конституции РФ 1993 г. и практике Конститущионного Суда РФ.

Современный российский конституционализм характеризуется опредеменным смещением в иерархии ценностей, однако подобное «смещение» не следует считать «коренным». Мы не отказались от демократии, верховенства прав человека, гуманизма и справедливости [12, с. 4] . Аостижения Конституции РФ 1993 г. сохраняются и продолжают действовать. Возможкно, россияне на некоторое время перестали их ценить и стали в них немного сомневаться. Этому способствует обнаружившийся культ патриотизма $[13 ; 14]$ и сопутствующее ему ослабление универсализма в конституционном праве. ОАнако в российском обществе достигнуто взаимное уважение вцасти и народа, что обеспечивается «западными» инструментами выборов и санкционируемого гражданами народного представительства. Партийно-тоталитарное государство реанимировать невозможно, Аа к этому никто и не стремится. Граждане в целом солидарны с целями государства и права, что подАерживает демократический конститущионный строй. В связи с этим, надо полагать, что конституционализм как таковой прочно утверждается в российском обществе, по крайней мере, в Аолгосрочной перспективе.

Будучи институтом демократического конституџионного строя, преАставительная Аемократия в течение последних 25 мет развивалась не менее сложно и противоречиво, чем сам конституџионный строй. Это Авижение можно охарактеризовать с помощью анализа Аействия принципов народного преАставительства, причем не только «классических» (всеобеег, равного, прямого избирательного права при тайном голосовании), но и более «современных», потому изменчивых, прочно не устоявшихся [15, с. 11] . В их числе, во-первых, баланс полномочий, во-вторых, профессионализм, в-третьих, партийность.

В 1993 г. наблюдалось противостояние «представительной» (Р.И. Хасбулатов) и «исполнительной» (Б.Н. ЕАьцин) власти, закончившееся декабрьской конституционной реформой. Результаты референдума о доверии власти и необходимости досрочного прекращения полномочий Президента и депутатов Верховного Совета были истолкованы каждой из ветвей власти в свою пользу [16, с. 172]. Парламент в известной мере «поддержкам» Конституционный Суд РФ. Затем «победа» исполнительной власти, которая выразилась, в числе прочего, в итогах референдума о принятии Аействующей Конститущии РФ, казалось бы, должна быма привести к системному и Аолгосрочному отступцению 
от принџипа баланса властных полномочий законодательной и исполнительной ветвей власти. Но эта, если так можно выразиться, «побеАа» исполнительной вмасти была «правовой» и не может быть названа, по удачному выражкению И.А. Иıьина, «хищнической» [17, с. 463-467]. Стремление к солидарности оказалось сильнее, чем раскол и вражда. Были учреждены Совет Федерации и Государственная Аума, которые достаточно активно «вкАючились» в усиленную законотворческую деятельность, избегая тем самым политического демарша против Президента РФ и осуществляемой им политики. Те же явления распространились на уровень субъектов РФ, где стало разрешенным региональное законотворчество. Вместо обсуждения излюбленного вопроса «за белых или за красных» депутаты переключили внимание на проџесс законодательного регулирования общественных отношений. В отсутствие Федерального закона «Об общих принципах организации законодательных (представительных) и исполнительных органов государственной вмасти субъектов Российской Федерации» конституциям и уставам субъектов РФ отводицась значительная регулятивная роль. В некоторых субъектах РФ учреждались конституционные или уставные суды. Все это Аемонстрировало развитие полномочий органов народного представительства [18], несмотря на итоги политического противостояния системы этих органов с исполнительной властью в 1993 г.

Конечно, принцип баланса полномочий заметно игнорировался вслеАствие ограниченности контрольных полномочий народного представительства. Аля российского конституционалиста до сих пор термины «парламентское расследование», «интерпемляџия» ици «вотум неАоверия» выглялят скорее как «западные», чем «отечественные» [19]. Счетная палата и Уполномоченный по правам человека не воспринимаются как инструменты парламентского контроля (их позиционируют в качестве «самостоятельных» органов в системе разделения властей). ОАнако сегодня с уверенностью можно утверждать, что институт контроля народного преАставительства успешно развивается в субъектах РФ, а в муниципальных образованиях он функционирует Ааже с некоторым «перебором» в ущерб самостоятельности всенародно избранных глав муниципальных образований [20]. На федеральном уровне, пусть и довольно осторожно, полномочия пацат парламента выравниваются вследствие конституџионных поправок о подотчетности Правительства РФ Государственной Ауме, а также законодательного решения об учреждении института парламентского расследования [21]. Таким образом, принџип баланса полномочий в системе разделения властей так или иначе соблюдается, хотя поиск путей его оптимизаџии в современной России продолжается.

Конституционный принџип «профессиональной» депутатской деятельности в течение послеАних 25 мет продемонстрировац более противоречивую картину развития. Напомним, что советская школа государствоведения особенно активно настаивала на таком преимуществе советского народного представительства, как совмещение Аепутатской Аеятельности с основной работой или служббой народных избранников. Считалось, что таким образом депутаты цучше осведомиены о текущих проблемах народной жкизни, обсуждают государственные и местные вопросы в трудовых комлективах, советуются с изби- 
рателями, получают от них формальные и неформальные наказы [22, с. 11] . Буржуазный подход к профессиональному преАставительству еАинодушно критиковался как вредный и неприемлемый для советского строя.

Постсоветский конституционацизм первоначаАьно «подхвати^» идею профессионацьного представительства как новую и перспективную. Но с течением времени она стала оџениваться критически, Ааже скептически. В числе прочего обнаружилось, что депутатская деятельность - это особый вид государственной деятельности, который нуждается в теоретико-методологических разработках, требует институционацизации в системе высшего образования и, что особенно важно, внутреннего стремления народного преАставителя к просвещению и парламентской культуре. Аیя профессиональной Аепутатской деятельности мало просто встречаться с избиратемями, проводить собрания, агитировать на митингах, выступать в прениях и парламентских дебатах. Нужен ответственный и анацитический подход к осмыслению тенденџий развития государства и права, собственное видение приоритетов в законодательной политике, глубокое понимание политических явлений и процессов, происхоАящих в стране и в мире [23] .

Профессиональное представительство порождает и ряд Аругих проблем. Аепутатам нужно, что называется, «ходить на работу», а это требует соблюАения ряда принципов и норм трудового права в отсутствие Аисциплинирующих механизмов во взаимоотношениях работника и работодателя в системе народного представительства. Уволить депутата как народного избранника по основанию нарушения им «трудовой дисципцины» весьма проблематично. Сложно даже обеспечить фактическое участие депутата в заседании органа народного представительства, так как народный избранник может быть в это время «занят» более важными «делами» с его точки зрения. Ответственность перед народом в ходе очередных выборов - слишком призрачный и отдаленный стимул правомерного поведения, который может быть полностью проигнорирован в случае отсутствия желания действующего депутата баммотироваться на новый срок.

Профессиональное представительство рождает в среде депутатов особую озабоченность по вопросу мьгот и привилегий [24; 25], включая денежное содержание, вспомогательный аппарат гражданских служащих, служебные автомобили, дополнительное пенсионное обеспечение и так называемые «золотые парашюты», которые «раскрывает» бюджетная система при вынужденном увольнении народных представителей в связи с их «неизбранием» на новый срок. Практически кажАый из названных институтов в течение послеАних 25 мет так или иначе затрагивался практикой конституционного правосудия, что неоспоримо свидетельствует об актуальности проблемы. Конечно, теми же иьготами и привилегиями пользуются соответствующие их рангу чиновники исполнительной власти. Но это считается как бы соответствующим естественному порядку вещей, чего не скажешь о народном преАставительстве как институте конституционной демократии.

На федеральном уровне представительство стало профессиональным сразу по итогам конституционной реформы 1993 г. В субъектах Федерации оно 
сочеталось с «непрофессиональным», в муниципальных образованиях сохранялось как «непрофессиональное» по преимуществу. Федеральный закон «Об общих принципах организаџии местного самоуправления в Российской Федерации» Аажке установиц квоту на места в преАставительном органе, которые могут замещаться на постоянной основе. Это, в свою очередь, породицо проблему обеспечения равенства депутатов, работающих на профессиональной постоянной основе, и народных представителей, которые совмещают депутатскую деятельность с основным местом работы или служкбы.

Их равенство в правах на внесение законопроектов, постановку вопросов на обсуждение, выступление в прениях и участие в голосовании никем не оспаривалось. Гцавную озабоченность вызывац вопрос о денежном содержании, вспомогательном аппарате гражданских служащих, служебных автомобимях, Аополнительном пенсионном обеспечении и компенсации при увольнении. Кроме того, в преАставительном органе возможна своя внутренняя иерархия Аолжностей (кроме «рядовых» Аепутатов - предсеАатель и заместители председателя органа, председатели и заместители преАсеАателей комитетов, комиссий, фракций и депутатских групп). Аолжен ми законодатель дифференцировать правовое регулирование с учетом этих факторов? Или народные представители должны быть равными в своем правовом статусе вне зависимости от указанных обстоятельств?

Еще одной проблемой конституционного развития преАставительной демократии в России в течение последних 25 мет стал вопрос о соотношении «партийного» и «внепартийного» преАставительства. В 1993 г. «mainstream» общественного мнения демонстрировац еще остатки течения «против» КПСС и ее «монопольного» положения как «руководящей и направляющей силы» советского общества [26, с. 11]. В связи с этим в Конституции РФ почти ничего не сказано о партиях и их роли в народном представительстве. ОАнако опыт «совершенно беспартийного» представительства с неограниченной помитической конкуренџией Аовольно быстро вызвал к жизни стремление законодателя к партийной институционализации [27].

В конечном итоге эта тенденция затронула даже представительство на уровне муниџипацьных образований, где партийный критерий явцяется наиболее спорным и, как слеАствие, в наименьшей степени преАпочтительным [28].

Этому способствовало ограничение права объединений граждан на выдвижение кандидатов. Сначала правом избирательного объединения пользовались все общественные объединения, затем - только политические общественные

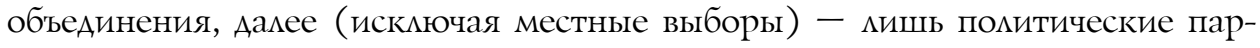
тии. На определенном этапе сбор подписей избирателей требовался дия всех кандидатов, что сопровождалось беспрецедентной практикой избирательных комиссий по проверке и выбраковке подписей граждан по надуманным основаниям и завышенным требованиям к их оформлению, что всецело полАерживалось практикой судов общей юрисаикщии. Чтобы избежкать этого, законодатель ввец институт избирательного залога. Через некоторое время залог быц упразднен. Партии, получившие преАставительство в парламенте, 
освобожАаАись от необходимости сбора подписей в подАержкку выАвижкения кандидатов, чем партийное строительство было окончательно стимулировано и упорядочено в избирательной системе России. Независимые кандидаты попрежнему несут обязанность сбора подписей избирателей в подАержку выдвижения на общих основаниях.

Аругим важным фактором активизации партийного строительства после конституционной реформы 1993 г. стала пропорџиональная формула преАставительства, которая сочеталась или даже не сочеталась с мажоритарной системой, но полностью ее заменяла. Субъекты РФ и муниципальные образования внеАряли пропорциональную систему Аовольно неохотно, в связи с чем потребовались соответствующие поправки в федеральное законодательство. Государственная Аума с начала своего функщионирования сочетала пропорциональное и мажкоритарное представительство, к чему была вынужкена вернуться после кратковременного опыта использования только пропорџиональной избирательной системы без бамлотировки кандидатов в мажоритарных избирательных округах.

Несмотря на все это, в России в течение 25 мет после принятия Конституџии РФ 1993 г. пока не сложилась устойчивая модель мирного соперничества крупньх политических партий, которые поочередно одерживали бы «победу» или «поражкение» в ходе очередных парламентских выборов, чем обеспечивали бы ротацию власти, учет меняющихся преАпочтений избирателей, демократичность конституционного строя в целом в результате смены правящей и оппозиционной политических сил [29] .

Полагаем, что это задача ближайшего будущего. Без ее конструктивного разрешения Аальнейшее развитие российского конституционацизма выглядит весьма бесперспективным.

Народ как носитель суверенитета и единственный источник власти имеет ряд общих потребностей и интересов (мир, безопасность, экономическое благосостояние и т.А. ), но никогда не был и не будет способным к формированию и выражению унифицированного общественного мнения. В демократическом обществе это проявляется особенно ярко. В народной среде скмадываются разАичные точки зрения, взгляды, подходы к решению политических проблем, которые меняются с течением времени и поА влиянием политических событий. В условиях авторитарного, не конституционного правления разнообразие политических взглядов в обществе можкет быть заблокировано или подавлено, однако это не уничтожает его в принџипе. Политически ангажированные СМИ, политическая пропаганда и агитация способны к определенному манипулированию общественным мнением, но данный институт также не может полностью унифиџировать политические взгляды и преАпочтения в народной среде.

Аоктрина конституционализма не просто подАерживает эту точку зрения. Конституционализм стимулирует политическое многообразие и многопартийность [30, с. 234; 31; 32]. В обществе не может быть оАной партии, одной идеологии, оАного «истинно верного» пути Аальнейшего развития. Конституционализм требует наличия ряда крупных политических партий или Аругих 
политических организаций, которые мирно соперничают Аруг с Аругом в ходе избирательных кампаний и пармаментских дебатов.

\section{Библиографический список}

1. Авакьян C.A. Конституционализм и публичная власть: концепции и перспективы // Конституционное и муниципальное право. 2013. № 11. С. 27-30.

2. Эбзеев Б.С. Конституции Российской Федерации - 20 лет: государство, демократия, личность сквозь призму практического конституционализма // Журнал конституционного правосудия. 2013. № 6 .

3. Князев С.Д. Стабильность Конституции и ее значение для современного российского конституционализма // Конституционное и муниципальное право. 2015. № 1. С. 4-12.

4. Кабышев В.T. Российский конституционализм на рубеже тысячелетий // Правоведение. 2001. № 4. C. 61-70.

5. Мамут Л.С. Критика политической идеологии анархизма // Советское государство и право. 1971. № 5. С. 42-52.

6. Королева Л.Г. Тема свободы личности в русском анархизме // Учебные записки РОСИ: Проблемы социально-гуманитарных дисциплин. Вып. 10. Курск, 2002. С. 3-21.

7. Сухова А.B. Анархизм в политико-правовой теории Н. Бердяева и в современности // Проблемы развития правовой системы современной России. Курган, 2009.

8. Аврутин Ю.Е. Избранные труды. О государстве и государственной власти, законности и правопорядке, публичном управлении и административном праве. СПб., 2017.

9. Грипп Э.Х., Патрикеев В.Е., Яхина Ю.Х. О некоторых аспектах деятельности органов внутренних дел в условиях чрезвычайных обстоятельств // Вестник Санкт-Петербургского университета МВД России. 2018. № 3. С. 38-41.

10. Тойбнер Г. Контуры конституционной социологии: преодоление исключительности государственного конституционализма // Сравнительное конституционное обозрение. 2016. № 1. C. 41-55.

11. Андреева Г.Н. Об истоках российского конституционализма и о месте России в мировых конституционных процессах // Lex Russica. 2016. № 3. C. 22-34.

12. Ескина Л.Б. Конституция России: стабильность и развитие // Журнал конституционного правосудия. 2018. № 5.

13. Нырков Н.В. Социокультурный подход к национальной идее, отечеству, патриотизму // Общество и право. 2014. № 1. С. 247-250.

14. Арипшев А.М., Машекуашева М.Х. Спекулятивный экстремизм или ложный патриотизм // «Черные дыры» в российском законодательстве. 2014. № 5. С. 81-83.

15. Чимаров Н.С. Проблемы реализации правовых избирательных стандартов новых технологий голосования в Российской Федерации и зарубежных странах: конституционно-правовое исследование: автореф. ... канд. юрид. наук. СПб., 2017.

16. Комаровский В.С. Апрельский референдум 1993 г.: пропаганда и результат // Технология и организация выборных кампаний: зарубежный и отечественный опыт. М., 1993.

17. Ильин И.А. Сильная власть. Русская идея. М., 2017.

18. Тихомиров Ю.А. Соотношение федерального законодательства и законодательства области как субъекта Российской Федерации // Законы области как субъекта Российской Федерации. Воронеж, 1996. С. 14-20.

19. Волчкова Н.Н. Парламентский контроль в зарубежных странах и возможности его использования в современной России // Современное общество и право. 2013. № 1. С. 96-103.

20. Астафичев П.А. Удаление главы муниципального образования в отставку как институт муниципального права // Вестник Санкт-Петербургского университета МВД России. 2018. № 3. C. 35-38. 
21. О парламентском расследовании Федерального Собрания Российской Федерации: Федер. закон от 27 дек. 2005 г. с послед. изм. // СЗ РФ. 2006. № 1. Ст. 7; 2013. № 19. Ст. 2315.

22. Масленников B.A. Полномочия трудовых коллективов в подготовке и проведении выборов народных депутатов // Советское государство и право. 1989. № 9.

23. Акимова Е.Я. Правовые аспекты совмещения депутатского мандата и внепарламентской деятельности в Германии и Австрии // Журнал конституционного правосудия. 2013. № 3. C. 33-38.

24. Ромашкова E.M. Гарантии и льготы, предоставляемые депутатам законодательных (представительных) органов государственной власти субъектов Российской Федерации // Государственная власть и местное самоуправление. 2000. № 2. С. 25-32.

25. Преснов И.Н., Стремоухов А.В. Социальные гарантии депутата Государственной Думы (индемнитет) // Социальное и пенсионное право. 2006. № 3. С. 2-7.

26. Авакьян С.A. Многопартийность и выборы: актуальные конституционно-правовые проблемы // Гражданин. Выборы. Власть: материалы III Международной научно-практической конференции. Пятигорск, 10-11 нояб. 2016 г. / отв. ред. Л.А. Тхабисимова. Пятигорск, 2016.

27. Гуторова А.Н. Принцип политической конкуренции как основа взаимодействия политических партий в демократическом государстве // Международная научно-практическая конференция, посвященная 20-летию Конституции Российской Федерации, г. Кемерово, 12 дек. 2013 г.: материалы докладов и выступлений. Кемерово, 2014. С. 73-76.

28. Оффердал $A$. Местное представительство: на примере мэров Словакии и Чехии // Центр. Регионы. Местное самоуправление: к новой концепции взаимоотношений (Россия и зарубежный опыт). М., 2000. С. 69-74.

29. Астафичев П.А. Демократия как основа доктрины конституционализма и конституционного строя современного государства // Конституционное и муниципальное право. 2014. № 7. C. 19-23.

30. Лапаева В.В. Право и многопартийность в современной России. М., 1999.

31. Шахрай С.М. Многопартийность в 1990-х годах. Парламент. Конституционный Суд Российской Федерации // Политические партии в демократическом обществе: правовые основы организации и деятельности: материалы международной конференции. М., 2013. C. $151-160$.

32. Володина С.В. Идеологическое многообразие и многопартийность в системе основ конституционного строя России // Вестник Саратовской государственной юридической академии. 2014. № 3. С. 209-212. 